\title{
Seed Transmission of Dahlia mosaic virus in Dahlia pinnata
}

\author{
V. Pahalawatta, K. Druffel, and H. R. Pappu, Department of Plant Pathology, Washington State University, Pull- \\ man 99164-6430
}

\begin{abstract}
Pahalawatta, V., Druffel, K., and Pappu, H. R. 2007. Seed transmission of Dahlia mosaic virus in Dahlia pinnata. Plant Dis. 91:88-91.

Dahlia is an economically important ornamental crop in the United States and several other countries in the world. Among the viral diseases that affect dahlia, Dahlia mosaic virus (DMV) is considered to be the most widespread and to have the greatest impact on flower production. Using grow-out tests followed by polymerase chain reaction (PCR)-based testing of the seedlings, dahlia seed obtained from three different sources were shown to contain DMV. Additionally, the distribution of DMV in various parts of the dahlia seed was determined by PCR. Growout tests revealed a high rate of seed transmission. DMV was detected in cotyledons and, rarely, in the seed coat. The virus also was detected in pollen collected from infected plants. In addition to vegetative propagation, seedborne infection could be contributing to the spread of DMV in dahlia. Use of virus-free seed and vegetative material would result in reduced incidence of the disease.
\end{abstract}

Dahlia mosaic virus (DMV), a member of the genus Caulimovirus, family Caulimoviridae, is an economically important viral pathogen of dahlia. First reported in Dahlia pinnata from Germany, the disease is prevalent in Dahlia spp. and has become one of the most dominant viruses in the floriculture and ornamental industry $(3,13)$. The disease is characterized by symptoms of mosaic, chlorotic vein banding, and leaf malformations; however, symptoms vary depending on dahlia cultivar (12). Dahlia cultivars with few or no symptoms are considered to be important reservoirs of virus. DMV is geographically widespread but the natural host range is limited to only Dahlia spp. (7). Previous studies of DMV transmission have resulted in identification of 16 aphid species, including Aphis fabae, Myzus persicae, and Macrosiphum euphorbiae (2), as vectors transmitting the virus in a nonpersistent manner. A virus-encoded aphid transmission protein is reported to be necessary for viral transmission (7). DMV also was shown to be transmitted by mechanical inoculation $(2,3)$. Previous studies of DMV report that the virus is not transmitted by seed $(2,3)$. However, there have been no studies to confirm this definitively. Partial molecular characterization of the DMV genome has

Corresponding author: H. R. Pappu

E-mail: hrp@wsu.edu

* The $\boldsymbol{e}$-Xtra logo stands for "electronic extra" and indicates that Figure 3 will appear in color in the online edition.

Accepted for publication 28 August 2006.

DOI: 10.1094/PD-91-0088

(C) 2007 The American Phytopathological Society been reported (GenBank accession nos. AY309480, AY309479, AY291588, AY291587, AY291586, and AY291585; $10,11)$ and detection of DMV based on polymerase chain reaction (PCR) and realtime PCR is now possible $(1,10,13)$.

A survey by Pappu et al. (13), using a PCR-based detection assay, of dahlia plants collected from several states in the United States, revealed a very high incidence of DMV in dahlia. Subsequently, numerous dahlia plants and seed from different locations within the United States were tested with the PCR-based detection assay. The majority of plants and seed tested positive for the presence of DMV, suggesting the occurrence of seedborne viral infection. However, there have been no systematic studies to unequivocally demonstrate seedborne viral infection or the potential of the virus to be seed transmitted. The objective of this study was to investigate seed transmission of DMV in dahlia, including whether DMV could be pollen-borne, under conditions that eliminate the possibility of introduction of the virus by aphids.

\section{MATERIALS AND METHODS}

Seed sources. Three commercially available seed sources of $D$. pinnata from
Kentucky, Tennessee, and Colorado were used in this study. In all, 20 seeds from each seed source were used: 10 seeds were used for virus detection in seed coat and cotyledon and the other 10 seeds were used for grow-out tests and testing for the virus in the resulting seedlings. In addition, five seeds each from two of the seed sources were grown in an insect-proof greenhouse. Plants were analyzed by PCR and inspected visually for development of DMV symptoms.

DNA extractions. Ten seeds from each source were soaked in distilled water for 2 to $4 \mathrm{~h}$ until the seed coat softened. Seed then were blotted dry and the seed coats were separated from the cotyledons using forceps. Total nucleic acid was extracted from the separated seed coats and cotyledons using the modified Dellaporta method $(13,14)$. The remaining 10 seeds from each seed source were allowed to germinate on moistened filter paper in covered petri dishes (100 by $15 \mathrm{~mm}$ ) to avoid exposure to insect vectors. After 9 to 10 days, when the first true leaves started to emerge, total DNA was extracted from the seedlings as described above. Four weeks after planting, a single leaf from each plant grown in the greenhouse also was used for total DNA extraction.

Detection of DMV by PCR. DMV isolate D10, originally isolated from an infected dahlia plant, was used to clone and sequence the viral genome. Based on the sequence information (11), primer pairs were designed for specific detection of DMV in dahlia. Three primer pairs representing three open reading frames (ORFs) of the DMV genome were used to detect the virus in the seed, seedling, and leaf samples (Table 1). Six additional primer pairs designed based on DMV sequences available in the GenBank (Accession nos. AY309480, AY309479, AY291588, AY291587, AY291586, and AY291585) also were used. The PCR reaction included a final volume of $2 \mu \mathrm{l}$ of $10 \times$ PCR buffer and a final concentration of $0.15 \mathrm{mM}$

Table 1. Dahlia mosaic virus (DMV)-specific primer pairs used for DMV detection by polymerase chain reaction

\begin{tabular}{llcc}
\hline Primer pair $^{\mathbf{a}}$ & \multicolumn{1}{c}{ Sequence $\left(\mathbf{5}^{\prime}-\mathbf{3}^{\prime}\right)$} & Temp $\left({ }^{\circ} \mathbf{C}\right)$ & Expected size $(\mathbf{b p})$ \\
\hline ORF1-START & ATGGATCGTAAAGATT & & \\
ORF1-END1 & CTGTTTTCTGTGTTTCTACTGG & 50 & 900 \\
ORF4CP1-1431F & TGCATAAAATGAGTTCTATC & & 480 \\
ORF4CPI-1926C & TGAACTTGTTCATCATTATC & 58 & 1,280 \\
ORF6-START & ATGGAAGAAATTAAGGCGT & & \\
ORF6-END1 & TTGTCTTCATCCATAAAGCAG & 60 & \\
\hline
\end{tabular}

a $\mathrm{Temp}=$ temperature and $\mathrm{ORF}=$ open reading frame. 
dNTPs, $2 \mathrm{mM} \mathrm{MgCl}_{2}$, and $0.6 \mu \mathrm{M}$ each primer in a total reaction volume of $20 \mu \mathrm{l}$. PCR amplification was performed in a DNA thermal cycler (BioRad, Hercules, CA) programmed for $3 \mathrm{~min}$ at $94^{\circ} \mathrm{C}$ for initial denaturation; 50 cycles each consisting of $30 \mathrm{~s}$ at $94^{\circ} \mathrm{C}, 20 \mathrm{~s}$ at $\mathrm{T}_{\mathrm{m}}$, and a $1-\mathrm{min}$ extension per $1,000-b p$ product at $72^{\circ} \mathrm{C}$; followed by a final extension for $7 \mathrm{~min}$ at $72^{\circ} \mathrm{C}$. Each PCR reaction included a DNA sample from a DMV-infected plant and a water control. The PCR products were analyzed by agarose gel electrophoresis in $1 \times$ Tris-acetate-EDTA buffer. PCR products representing each ORF were cloned and sequenced to verify the identity of amplified fragments.

\section{RESULTS AND DISCUSSION}

DMV was detected in the cotyledons of all seed analyzed with the three primer pairs specific for DMV. The PCR reaction

Table 2. Detection of Dahlia mosaic virus (DMV) by polymerase chain reaction (PCR) in seed and seedlings from three different commercial seed sources

\begin{tabular}{lccc}
\hline & \multicolumn{3}{c}{ No. positive for DMV/no. tested } \\
\cline { 2 - 4 } Source, primer pair ${ }^{\mathbf{a}}$ & Seed coat & Cotyledon & Seedlings $^{\mathbf{b}}$ \\
\hline Tennessee & $0 / 10$ & $10 / 10$ & \\
ORF1-START, ORF1-END1 & $0 / 10$ & $10 / 10$ & $10 / 10$ \\
ORF4CP1-1431F, ORF4CP1-1926C & $0 / 10$ & $10 / 10$ & $10 / 10$ \\
ORF6-START, ORF6-END1 & & & \\
Kentucky & $0 / 10$ & $10 / 10$ & $10 / 10$ \\
ORF1-START, ORF1-END1 & $0 / 10$ & $10 / 10$ & $10 / 10$ \\
ORF4CP1-1431F, ORF4CP1-1926C & $0 / 10$ & $10 / 10$ & $10 / 10$ \\
ORF6-START, ORF6-END1 & & & \\
Colorado & $0 / 10$ & $10 / 10$ & $10 / 10$ \\
ORF1-START, ORF1-END1 & $1 / 10$ & $10 / 10$ & $10 / 10$ \\
ORF4CP1-1431F, ORF4CP1-1926C & $0 / 10$ & $10 / 10$ & $10 / 10$ \\
ORF6-START, ORF6-END1 &
\end{tabular}

${ }^{\text {a }}$ Dahlia seed source and PCR primer pair; ORF = open reading frame.

${ }^{\mathrm{b}}$ Seedlings were tested when 9 to 10 days old and asymptomatic.

with primer pair ORF1-START/ORF1END1, representing the first ORF, produced an amplicon of 900 bp. Similarly, the primer pair ORF4CP1-1431F/ ORF4CP1-1926C, representing ORF4, produced an amplicon of $480 \mathrm{bp}$, and the primer pair ORF6-START/ORF6-END1, representing ORF6, produced an amplicon of 1,280 bp. All amplicons produced were within the expected size range for DMV. In contrast, the virus could not be detected in the seed coat except in two cases where seed coats from two seeds were positive for DMV using the primers derived from ORF 4 (Table 2; Fig. 1). All seedlings obtained from seed germinated on filter paper also tested positive for the presence of the virus with each of the three primer pairs (Table 2; Fig. 2). Similarly, DNA extracts from 4-week-old leaf samples taken from the plants grown in the greenhouse also were positive for DMV when tested by PCR, although the plants were asymptomatic (Fig. 3A). All of these plants developed mosaic symptoms, to varying degrees, 5 to 7 weeks after planting (Fig. 3B). The six primer pairs designed based on DMV sequences available in the GenBank failed to produce any amplicons.

Our results indicate that DMV is seed transmitted in dahlia. All of the seed ana-

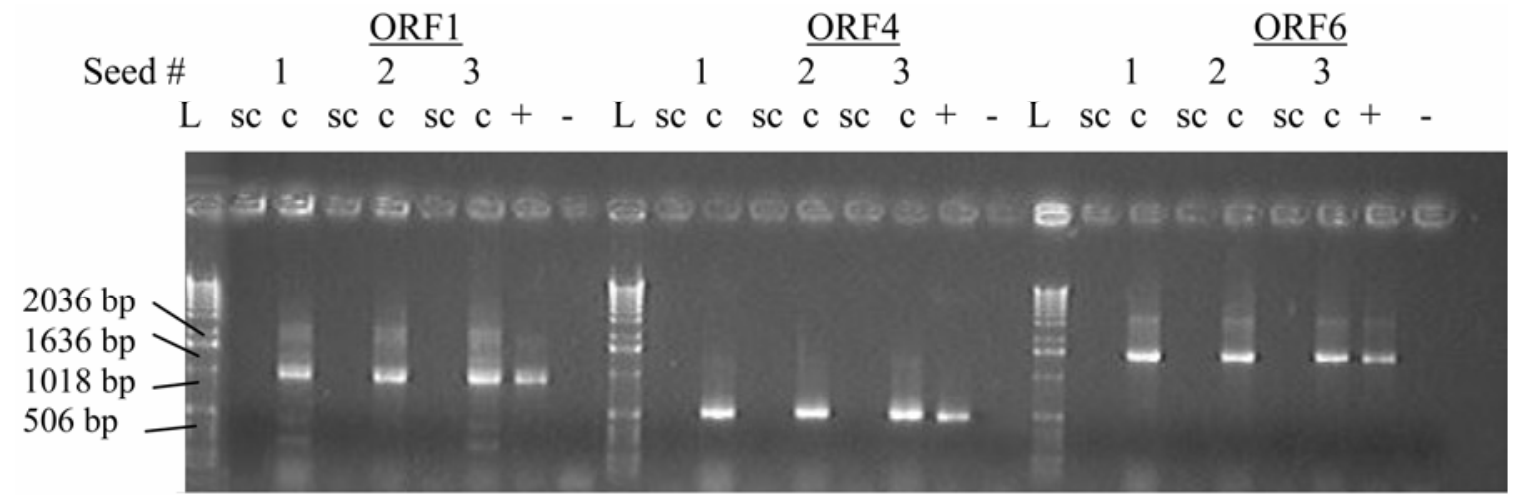

Fig. 1. Agarose gel electrophoresis of polymerase chain reaction (PCR) products from DNA extracts of dahlia seed coats and cotyledons amplified with Dahlia mosaic virus-specific primer pairs. Representative sample of PCR products for DNA extracts of dahlia seed amplified with open reading frame (ORF)1-START/ORF1-END1 (ORF1), ORF4CP1-1431F/ORF4CP1-1926C (ORF4), and ORF6-START/ORF6-END1 (ORF6). Sc, seed coat; c, cotyledon; + , positive control; -, negative control; L, 1-kb DNA ladder.

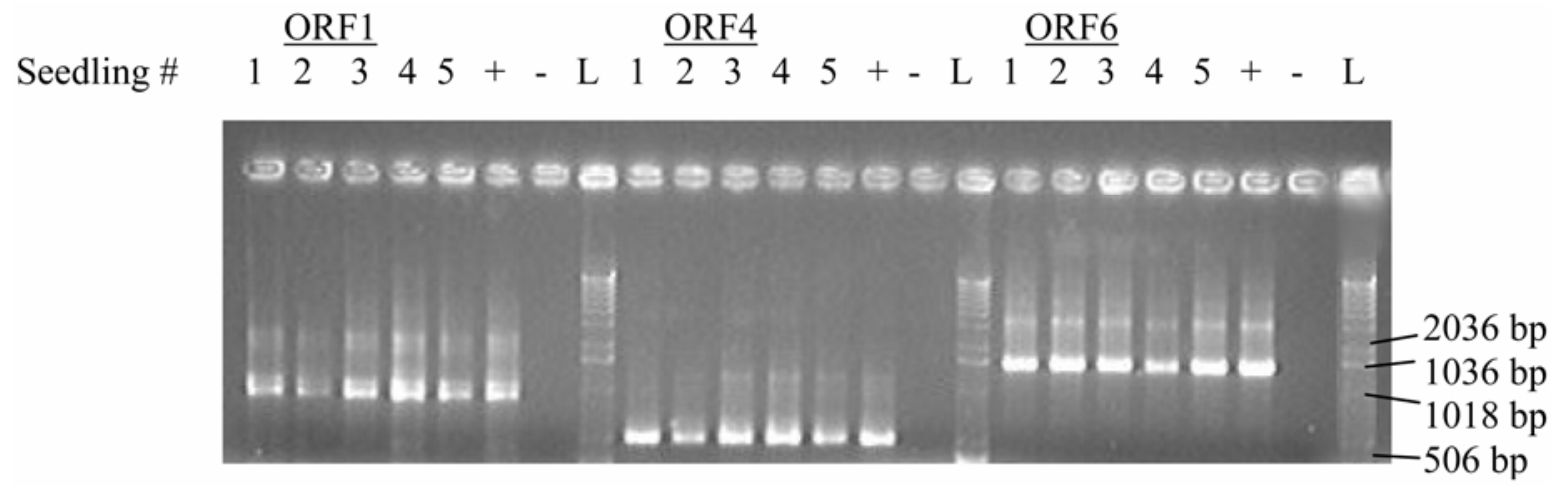

Fig. 2. Agarose gel electrophoresis of polymerase chain reaction products from DNA extracts of 9- to10-day-old dahlia seedlings germinated in covered petri dishes and tested with Dahlia mosaic virus-specific primer pairs. Open reading frame (ORF)1, ORF1-START/ORF1-END1; ORF4, ORF4CP11431F/ORF4CP1-1926C; ORF6, ORF6-START/ORF6-END1; +, positive control; -, negative control; L, 1-kb DNA ladder. 
lyzed using the PCR-based assay tested positive for DMV, demonstrating the seedborne nature of the virus. Generally, whole-seed viral assays are considered unsuitable in estimating the rate of seed transmission because viral presence in the seed coat has no correlation to virus transmission from seed to seedlings $(4,8)$. In our study, dahlia seed coats and cotyledons were separated and individually tested for DMV. The results showed that the viral infection was associated primarily with the cotyledons and rarely with the seed coat. It is possible that the occasional detection of the virus in the seed coat may have been due to remnants of the cotylecomponents were separated. Due to the small size of the dahlia seed, it was not possible to separate the embryo axis from cotyledon. Seed transmission was confirmed by detecting DMV in very young seedlings ( 9 to 10 days old) that were gerdon on the seed coat when the two seed

minated in covered petri dishes, which excluded the possibility of virus transmission by aphid. We also found that DMV could be amplified in total DNA extracts of pollen collected from dahlia flowers of infected plants (Fig. 4). Furthermore, viruses transmitted through seed are reported to have certain common characteristics (6), such as mechanical transmissibility, narrow host range among annual plants, and vector transmission in a nonpersistent manner, which also are exhibited by DMV. Another caulimovirus, Cauliflower mosaic virus, has been reported to be seedborne due to the occurrence of the virus in the seed testa (16), although no subsequent transmission to seedlings was recorded. The frequency of seed transmission for plant viruses varies from 0 to $100 \%$ and rarely exceeds $50 \%$ for most viruses (9). It was reported that plant pararetrovirus DNA might integrate into host chromosomes $(5,15)$. Research is in progress to deter-
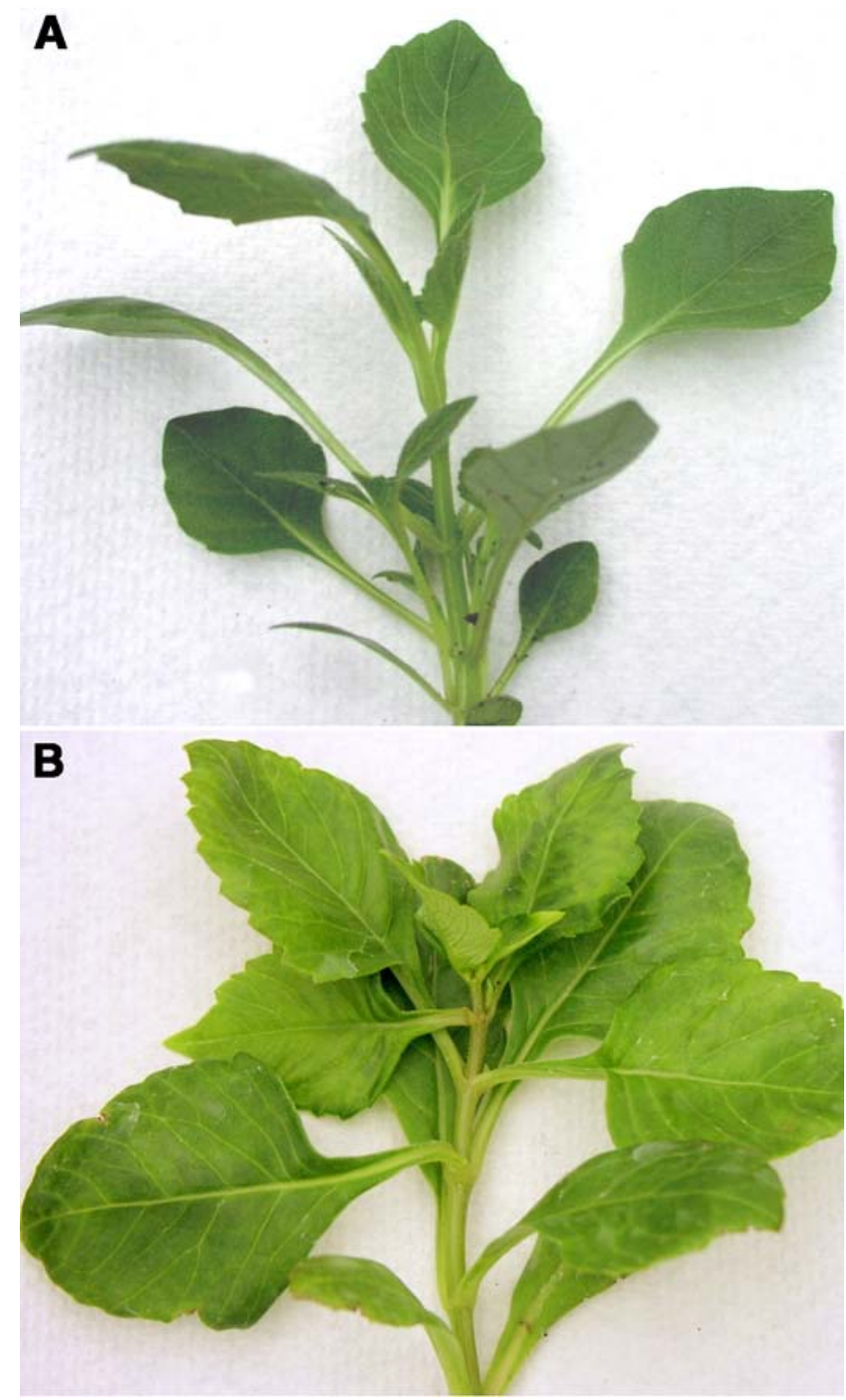

Fig. 3. Seedlings positive for Dahlia mosaic virus (DMV) by polymerase chain reaction. A, Asymptomatic 4-week-old DMV-infected dahlia seedling grown from seed under aphid-free conditions; B, DMV-infected seedling displaying symptoms (mosaic and chlorosis) at 5 to 7 weeks after planting. The seedling was grown from seed under aphid-free conditions. mine whether the high frequency of detection of DMV sequences in dahlia could be due to such an event.

The high rate of seed transmission of DMV combined with delayed symptom development, both observed in this study, may be partly responsible for the widespread occurrence of the virus in the United States (13). Four-week-old dahlia plants tested positive for DMV; however, symptoms were not evident until 1 to 3 weeks later. This demonstrates the need for testing young plants for DMV because asymptomatic infections contribute to inadvertent distribution of virus-infected material and its subsequent propagation.

The six primer pairs designed from the DMV sequences available in GenBank did not produce any amplicons. This could be due to the limited sequence homology between the D10 isolate used in this study and those available in GenBank. Also, amino acid sequence similarity between D10 and those available in GenBank ranged from 49 to $73 \%$ for the three ORFs represented by the amplicons obtained using D10-specific primers. Preliminary sequence data obtained in our laboratory and reports (10) suggest that there are at least three distinct populations potentially associated with dahlia mosaic. Therefore, it is highly probable that the DMV sequences in GenBank are not represented in the DMV isolates used in this study.

One of the biggest setbacks to detecting DMV and eliminating diseased plants is the propagation of infected plants and continued production of plants with asymptomatic infections. The results of this study demonstrate the potential role of seed transmission in the spread of DMV. Although the majority of dahlia propagation is through tubers, control options should include use of virus-free seed to reduce the impact of DMV.

\section{ORF6}
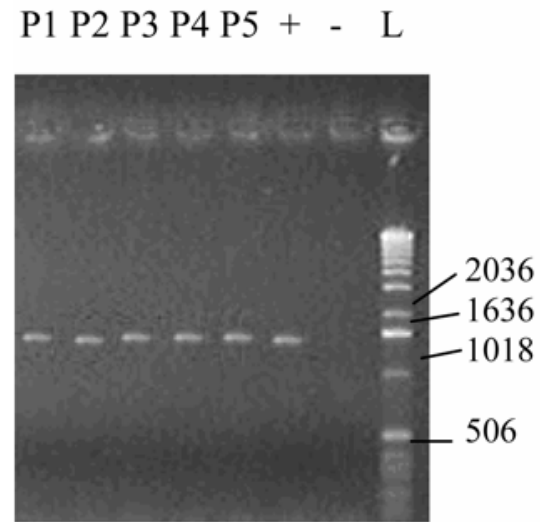

Fig. 4. Agarose gel electrophoresis of polymerase chain reaction products amplified with Dahlia mosaic virus-specific primer pair open reading frame (ORF)6-START/ORF6-END1 from DNA extracts of pollen collected from virus-infected dahlias; +, positive control; -, negative control; L, 1-kb DNA ladder. 


\section{ACKNOWLEDGMENTS}

Research was supported in part by the Samuel and Patricia Smith Endowment for Dahlia Virus Research, created by the American Dahlia Society. PPNS No. 0431, Department of Plant Pathology, College of Agricultural, Human and Natural Resource Sciences, Agricultural Research Center, Project \#WNP0545, Washington State University, Pullman 99164-6430.

\section{LITERATURE CITED}

1. Bogunov, Y. V. 2006. Identification of Dahlia mosaic virus with molecular biological methods. Mol. Biol. 40:184-185.

2. Brierley, P., and Smith, F. F. 1950. Some vectors, hosts and properties of dahlia mosaic virus. Plant Dis. Rep. 34:363-370.

3. Brunt, A. A. 1971. Some hosts and properties of dahlia mosaic virus. Anal. Appl. Biol. 67:357-368.

4. Gillaspie, J. A. G., Hopkins, M. S., and Pinnow, D. L. 1993. Relationship of cowpea seedpart infection and seed transmission of blackeye cowpea mosaic potyvirus in cowpea. Plant Dis. 77:875-877.

5. Jakowitsch, J., Mette, M. F., van der Winden,
J., Matzke, M. A., and Matzke, A. J. M. 1999. Integrated pararetroviral sequences define a unique class of dispersed repetitive DNA in plants. Proc. Natl. Acad. Sci. USA 96:1324113246.

6. Johansen, E., Edwards, M. C., and Hampton, R. O. 1994. Seed transmission of viruses: Current perspectives. Annu. Rev. Phytopathol. 32:363-386.

7. Lobenstein, G., Lawson, R. H., and Brunt, A. A. 1995. Pages 266-267 in: Viruses and Viruslike Diseases of Bulb and Flower Crops. John Wiley and Sons, Chichester, NY.

8. Maury, Y., Bossennec, J. M., Boudazin, G., Hampton, R., Pietersen, G., and Maguire, J. 1987. Factors influencing ELISA evaluation of transmission of pea seed-borne mosaic virus in infected pea seed: seed-group size and seed decortication. Agronomie 7:225-230.

9. Mink, G. I. 1993. Pollen- and seed-transmitted viruses and viroids. Annu. Rev. Phytopathol. 31:375-402.

10. Nicolaisen, M. 2003. Partial molecular characterization of Dahlia mosaic virus and its detection by PCR. Plant Dis. 87:945-948.

11. Pahalawatta, V., Pappu, H. R., and Druffel, K.,
2005. Molecular characterization of Dahlia mosaic virus and development of detection tools. (Abstr.) Phytopathology 95:S79.

12. Pappu, H. R., and Wyatt, S. D. 2003. Dahlia mosaic virus. A description of symptoms on dahlia. APSnet Image of the Week Online/2003/IW000032.asp.

13. Pappu, H. R., Wyatt, S. D., and Druffel, K. L. 2005. DMV: Molecular detection and distribution in dahlia in the US. HortScience 40:697 699.

14. Presting, G. G., Smith, O. P., and Brown, C. R. 1995. Resistance to potato leaf roll virus in potato plants transformed with the coat protein gene or with vector control constructs. Phytopathology 85:436-442.

15. Schoelz, J. E., Wiggins, B. E., Balaji, B. Palukaitis, P. F., and Squires, J. 2005. Integration of Cauliflower mosaic virus into the genome of Arabidopsis thaliana through a mechanism involving homologous recombination. XIIIth Int. Congr. Virol. San Francisco.

16. Tomlinson, J. A., and Walker, V. M. 1973. Further studies on seed-transmission in the ecology of some aphid-transmitted viruses. Ann. Appl. Biol. 73:292-298. 